PAPER

\title{
Doing good medical ethics: a Christian perspective
}

\author{
John Saunders
}

\section{Correspondence to}

Professor John Saunders, Department of Medicine, Nevill Hall Hospital, Brecon Road, Monmouthshire NP7 7EG, UK; saundersjohn@doctors.org.uk

Received 14 September 2014 Revised 28 October 2014 Accepted 29 October 2014

\begin{abstract}
Despite the rise of the secular state, religion remains a significant force in society. Within Christianity this encompasses a wide variety of beliefs. These range from simple assertions of theism in a cultural context to complex theologies; from liberal emphases on uncertainty and exploration to dogmatic views of divine revelation. How one 'does' good medical ethics depends on these perspectives. Contingently, the Christian contribution to medical ethics has been huge and constructive. Central to that contribution is a core belief in the intrinsic value of human life, respect for which we are accountable to God. Christianity continues to deserve its place 'in the public square' and, specifically, in medical ethical discourse.
\end{abstract}

\section{RELIGIOUS DECLINE?}

Sometimes it seems that religion must be an intellectual lost cause: a profusion of books, papers and chat shows attack its value, attribute any number of evils to its practice, criticise its social attitudes, ridicule its claims, deny its role in a secular society. The Christian religion, for example, does more harm than good, is responsible for war, persecution and censorship, treats sexual minorities and women unequally, promotes preposterous ideas similar to believing in fairies at the bottom of the garden and has a privileged role in many societies that should firmly be suppressed. As for medical ethics, its role should be identical to that in other disciplines: it should not have one. Medical ethics is an independent discipline that has no need of any help from religious thinking; moral theology should not exist, except as a form of anthropology. If theology is concerned first and foremost with God, then it has nothing meaningful to talk about-or, if it supposes it has, it should not be so rude as to do it in public. Intelligent people don't believe in all that stuff. Religion is in retreat, as Matthew Arnold expressed it in his Dover Beach: 'the sea of faith' emits only its 'melancholy, long, withdrawing roar, retreating'. God is dead. 'Some palliative care has been available for those left fatally infected by contact with the corrupting effects of the erstwhile patient. But ... such victims (should) seek alleviation of their nastiest symptoms in private. Moribund as these poor souls are, it is expedient that they too be confined to a place of effective entombment, in an underworld of cultural marginality where they can wreak harm only on their fellow shades', ${ }^{1}$ marginality outside, of course, the medical ethics journal or ethics committee.

But modernity, including medicine, is confronted by a host of threats and challenges. To these, religiosity has arisen in any number of forms: 'reconfigurations of traditional faiths, syncretisms of innovative and vestigial styles, smorgasbord spiritualities, pastiche instantiations of invisible as well as visible conceptions of transcendence, charismatic movements, interest in magic and the occult, neo-paganisms, apocalypticisms, fundamentalisms - and so on'. ${ }^{1}$ There are good and bad religiosities, good and bad ideologies, good and bad cultural values; and a great deal that is vacuous. A society requires sensitive dialogue in defining the limits of its tolerance, the extent to which individual choices should be curtailed.

Beyond these reactions, the world's great faiths continue to flourish. The vitality, diversity and political significance of Islam hardly requires comment, 'but the dramatic expansion and changes in Christianity in Africa, Asia and Latin America; the growing religious diversity in former communist countries; the proliferation of new religious movements globally; the power of new religious media, not least the internet; the immensely complex picture of religion in North America, even Europe ${ }^{1}$ — these demand a voice and a voice, moreover, in the public square. The world is not coming of age if by that we mean abandoning God. It is not the religious who are in denial. 'In spite of everything, [people] go on saying "God"'.2 Even in secular Britain we can crudely say that $30 \%$ are believers, $30 \%$ the fuzzy faithful and the rest of no religious belief. If religion thinks it has something to say about medical ethics, it should have the opportunity to say so.

\section{NATURAL THEOLOGY, REVEALED RELIGION?}

Towards the end of his life the Nobel literature laureate Isaac Bashevis Singer surprised his interviewer by expressing belief in God. ${ }^{3}$ The interviewer inquired further, only to receive the mild answer that he, Singer, hadn't found a better explanation of why we were here. Existence was mysterious and nothing was certain. Although steeped from his childhood in Judaism, Singer's affirmation was undoctrinal, liberal and, some might say, woolly - a world away from the dogma of the Islamists of northern Iraq. This sort of theism, insofar as it articulates its origins, comes out of the traditions of natural theology, the product (in the Kantian sense) of transcendent reason. In the Judaeo-Christian writings, Singer's type of theism owes most to the Hebrew wisdom literature: ${ }^{4}$ Ecclesiastes, Job, Proverbs, parts of the Psalms and some of the apocryphal writings. The difference in these writings is that they are not concerned with God's special historical revelation through the prophets, but the idea that the one God embedded truth within all reality. God is discerned in a general as opposed to a special 
revelation and wisdom must mine its seams. Such theism permits—indeed encourages—scepticism, acknowledges ambiguity, reminds us that religion-or religious practice-can easily become an instrument of cruelty unless tempered with the sceptic's honesty, and it offers an alternative to prophetic revelation. It accepts living with questions or provisional answers and makes a virtue of living with uncertainty, with truth that may be provisional. It is a world away from religion as the enemy of mankind, a force to be extinguished by enlightened thinkers. ${ }^{5}$ Rather, it suggests that dialogue may be a better way ahead. Part of that dialogue might be a recognition that people of faith or faith communities may be far from the common caricature that portrays them as irrational zealots. Those of no faith require some understanding of the spectrum and nature of belief to inform their opinions. The ignorance of religion and religious history among cultural elites today impoverishes a dialogue of mutual respect.

Singer's simple credo, put into a cultural context, can offer an intellectually attractive formula for many a modernist. The theologian Keith Ward comments that, when Job says "I know that thou canst do all things", ${ }^{6}$ he is making one of the few doctrinal statements in the Old Testament. But, he asks, how do we know that God is omnipotent, 'except by using reason as best you can to unfold its implications and presuppositions'? He continues: ${ }^{7}$

So belief in God may not be founded on reason, as though it is a hypothesis to explain the way the universe is the way it is. But reason has to get to work on those human experiences that give rise to a belief in God, to try to sort out which experiences are reliable and trustworthy... and see how such ideas relate to other knowledge of the world, derived from other forms of human experience. This is quite a lot of work for reason to do, even if it comes with a health warning that the ways of God are ultimately beyond human understanding.

I think this hardly novel but, rather, a modern approach to the wisdom literature.

Religion, according to one definition, ${ }^{8}$ is 'commitment to a kind or quality of life that purports to recognise a source beyond itself (usually but not necessarily called God), and that issues in recognisable fruits in human conduct (eg, law, morality), culture (eg, art, poetry) and thought (eg, philosophy)'. Consider this, by contrast: ${ }^{9}$

\begin{abstract}
All react to experience with some form of love or enjoyment or fear or rage, except those driven to shelter from the ambiguous rain of life under some dreadful apathy. Religion concerns some attempt to sift and understand those reactions, organise them into a coherent attitude, arrange a readiness in oneself for more of the happier sort. Everyone is religious in this sense.
\end{abstract}

In the first definition, religion is about belief: the recognition of a source beyond itself. In the latter understanding, theismand, for the author, Christian theism-is one lens through which to interpret experience, the emphasis being on the 'doing' rather than the doctrines of God's self-revelation. The possibilities of its application in medical ethics are not difficult to see.

\section{VARIETY OF 'GOD TALK' WITHIN CHRISTIAN BELIEF?}

Thought about God varies between the extremes of existentialism and cosmic piety. In the former, the divine requirement makes itself felt as an inner demand of which God is the mythologised expression of the demand and promise of moral responsibility (Fritz Buri), hope for the future (Jurgen Moltmann), love and the dimension of 'depth' in life (John Robinson) or the pursuit of spiritual liberation (Don Cupitt) and so on. ${ }^{10}$
By contrast, others (Hans Küng) insist on God with a cosmic dimension, ${ }^{11}$ without mediaeval metaphysics or crude Biblicism. The variety is huge, yet essential to understand Christian theism.

Defining what constitutes a Christian is similarly difficult. Even ignoring institutional and denominational boundaries, there has long been a difference of emphasis between those inspired by the peripatetic Jewish teacher's parables and his 'sermon on the mount' and, on the other hand, those worshipping Jesus as a manifestation of God. Many Unitarians or Quakers express beliefs close to atheism, whereas charismatic pentecostalists inhabit a world of miracle, creationism and biblical inerrancy. Russell ${ }^{12}$ thought that all the great historical religions have a church, a creed and a code of morals. It seems equally arguable that they may have none of these. Religions overlap (Druse, Baa'hi), while Russell seems to classify both Marxism and Naziism as religions.

How then one 'does' medical ethics from a specific religious perspective challenges the concepts of both 'specific' and 'religious'. Christianity, the largest of world religions, encompasses a huge range of viewpoints both in belief and practice. That is evident at its outset from the divergent approaches found in John's gospel compared with the other three. For philosophers, the element of belief has been of greater interest than practice, but Christianity's interaction with a variety of cultures has led to an iteration between the two. The 'ordinary religious believer is probably not very reflective about his beliefs. He may be able to utter appropriate formulae, but he may not be able very well to explain these or defend them... The philosopher's analytical or critical approach ... is likely to miss the religious point of belief'. ${ }^{13}$ An orthodox account of that point or purpose of belief is as a commitment 'to a self-transforming way of living in the world, in response to an experience of transcendent power and value, whether one's own or another's, received in trust. It involves one's deepest personal commitments and orders all one's life towards a hoped-for vision of and union with God'. ${ }^{14}$ None, of course, do order all their lives in that way-Christians are no more virtuous than others. But it is the element of personal commitment that generates the passion with which many people of religious belief raise their voices in ethical debate.

\section{PERPLEXITY AND TOLERANCE}

The 17th century Bishop of Gloucester, Miles Smith, wrote that 'man hath but a shallow sound, and a short reach, and dealeth onely by probabilities and likely-hoods'. ${ }^{15}$ Christian moral perplexity is not a new phenomenon and could hardly be otherwise given the variety of Christian beliefs, even within a broad umbrella of the main denominational orthodoxies. The result can be seen historically in the development of religious tolerance in the West, perhaps especially associated with England and the Netherlands. Elizabeth I famously declared that she would not open windows into men's souls. Tolerance advanced with the polity of the English republic ${ }^{16}$ (especially for Jews) and Locke's exposition ${ }^{17}$ later in the 17 th century gave an intellectual underpinning to the freedoms and tolerance we enjoy today. Tolerance remains a rarity in too many places in today's world and intolerance has been too great a practice of religious institutions. There is, crudely put, good and bad religion. In bringing any religious perspective to bear on medico-moral issues, a willingness to listen and courtesy in debate are necessary.

Christian thinking has occupied, contingently in the UK, a key role in the development of debate in modern medical ethics. This may reflect the heavy emphasis on personal behaviour in the Christian scriptures, especially the command to 
practical love (agape), the historical role of the English church in education and political organisation as well as the widely held views within Christian institutions towards public policy issues such as sexuality (divorce, reproduction, abortion, sexuality itself) and the end of life. Further, a number of key individuals of faith played a major role in bringing medical ethics into professional discourse: among others, Edward Shotter (founder of the London Medical Group, the Institute of Medical Ethics and this journal), Alastair Campbell, Gordon Dunstan, Kenneth Boyd, Brendan Callaghan. A series of thoughtful reports has come from the Linacre Centre, a Roman Catholic forum now renamed the Anscombe Bioethics Centre, and from the erstwhile Board of Social Responsibility of the Church of England -among several others of UK churches. These contributions are far from the dogmatic and negative caricature beloved of some critics. However, the theological input into these documents and expressions of opinion has sometimes been thin. For example, although churchmen have mainly taken a conservative view on legalising euthanasia and assisted suicide, the arguments they put forward rarely differ from those of an entirely secular background. ${ }^{18}$ In part this is explained by the developments in thinking resulting from 19th century biblical scholarship. Few intelligent Christians regard the Bible as a quarry for quotations which would give an authoritative ruling on a medical ethical issue. Confidence in the New Testament as a largely reliable account of the life and teaching of Jesus may have been shaken so that biblical interpretation requires greater care. A preferred approach may be an emphasis on the creativity of the moral teaching of Jesus as recorded in the gospels, in contrast to the rigid moralism of the Pharisees. Divine commands for modern living do not emanate directly from the Christian scriptures.

'Doing' medical ethics consists of identifying the medicomorally relevant facts in a particular situation; evaluating their significance in relation to the other facts; and then coming to a judgement about their rightness, wrongness, goodness or badness. In making that judgement, criteria are applied. These involve ethical principles, balancing conflicting principles against each other. Such principles are not capable of universal agreement; for example, absolute deontological principles are unacceptable to a utilitarian. From a religious perspective, value judgements may arise that relate to the particular tradition. Christianity has a particularly rich tradition, extending back over about 3000 years. However, it does not offer a set of ethical principles. 'Doing' medical ethics from a Christian perspective may have nothing to add in most instances from the principles used in judgements made by those of other faiths or none. In practice, many ethical standards are universal: almost all countries, for example, are signatories to the UN Declaration of Human Rights and almost all follow the Helsinki Declaration that describes the ethics of medical research. So, often the religious perspective offers nothing extra. This should surprise no one with an elementary understanding of cultural history and the roots of both ethics and law in the West. If Christians attribute their respect for human beings on the basis of belief in the fatherhood of God, many traditional socialists will ground it in the brotherhood of man, which in practice comes to the same thing. Christians may claim a Christian motivation or inspiration, but there is no such thing as a Christian ethic. ${ }^{19}$ Christ did not set out an ethical code. Certain standards are unchanging in the midst of relativity and flux, but the content of Christian morals changes; the distinctively Christian response is to accept the belief in the demands of God's love (agape) and work out its meaning in responding to others, to see the divine image in our neighbour.

\section{CHRISTIANITY IN WIDER SOCIETAL DEBATE}

'Doing' medical ethics from a religious perspective has arisen recently for at least three reasons. First, the ability of medical technologies to do more has brought questions that bear upon traditional Christian moral teaching: abortion, artificial insemination, embryo experimentation. Church institutions and leaders have pronounced in all these areas. Second, the substantial role of Christian bodies in education and in end of life hospice care has been challenged. The allocation of public funds to support 'faith schools' or hospices is easily portrayed as the subsidy by the secular state of specific religious communities-at worst, as the indoctrination of the young mind or indirectly proselytising the dying. Third, the impact of immigration into many European countries has seen an increased variety of cultural and religious ideas throughout society. Some of these ideas are shared with those of all beliefs and of none; others are highly individual. The 'secularising' element in Christian theology probably makes its contribution to societal discussion easier than that of other faiths. The danger is that an area for discussion easily becomes seen as a threat. All Western nations have historically developed from religiously-based polities into secular societies. Supposedly aggressive secularism, perhaps especially anti-Christian rhetoric, has produced its own strident counter-reaction, not all of it well informed. Evangelical Christian voices have been part of that strident response.

A public policy which denies advantage or preference to any one religious body, so-called 'procedural secularism', seems eminently desirable. The procedurally secular state offers no special benefits to any specific religious grouping and ensures that those of any religious conviction or none are protected in the practice of their beliefs, with no favoured status for any particular community. Against this, programmatic secularism attempts to create a loyalty to the state unencumbered by any private convictions. This may create particular difficulties for the religious believer. For society in general, larger commitments and visions from the religious perspective enrich public discourse and their suppression would impoverish a liberal society. ${ }^{20}$ In doing medical ethics, the religious voice still needs to be heard.

Historically, Christianity's emphasis upon loving one's neighbour led to the foundation of hospitals and infirmaries, to the training of the embryo healthcare practitioner, to the rituals that surround birth and death. It also emphasised human equality before God, forgiveness and the sacredness of human life. Christianity developed as an opponent to the casual murderousness of the Roman Empire in which it was born, a pacifist religion which subsequently made its accommodation with the state by developing a theory of the just war. That belief in the sanctity of human life has featured, for example, in the opposition of the Western Roman Catholic Church against abortion. Abortion exemplifies the value of a religious dimension to public debate (whether one agrees with it or not). The debate is often framed in terms of maternal choice versus fetal status as a person. However, the late Ronald Dworkin ${ }^{21}$ reframed the debate in terms of the sacred, arguing this as the historical Catholic position. His argument begins from the concept of intrinsic value: that some things are valuable independent of whether they serve a particular function: 'it is intrinsically regrettable when a human life, once begun, ends prematurely ... even when it is not bad for any particular person'; that is-life has more than instrumental value or subjective value (how valuable being alive is to the person concerned). The fetus may have neither. The traditional Christian argument is that life, as God's gift, is intrinsically valuable and therefore sacred. Dworkin enlarges the concept of the sacred, cuts it free from its religious roots. In so 
doing, he opens the possibility of a more productive discourse between pro- and anti-abortionists. It is a valuable approach that owes its origin to the Judaeo-Christian ethic towards life-promoted, in the abortion context, particularly by Roman Catholicism. I quote this example as demonstrating how a religious perspective can enrich public discourse and how its suppression would impoverish a liberal society.

There is nothing special about this in a multifaith/no faith society, or in one where the state is necessarily and desirably secular. Tolerance, as Locke set out, is rationally defensible and socially necessary if all are to live in harmony, where there cannot be agreement on many-if not most-matters of ultimate value.

Of course, cultural practices should be taken into account and there may be occasional clashes in any liberal society. For example, English case law stipulates that scarification marks on the face of a child are illegal whatever the cultural justification and English statute law prohibits female genital mutilation. Some believers will also argue for a special space for conscientious objection-an issue that has arisen in the context of abortion debates and will arise should assisted suicide or euthanasia be legalised in the UK. But it seems likely that believers or nonbelievers will have similar views on the desirability of conscientious objections and its tolerance, at least on these issues.

Many years ago I encountered a pregnant diabetic woman with a history of heart disease. She was in her mid-30s and pleased to be pregnant. The limited published literature suggested that pregnancy continuation gave a 50\% maternal mortality risk. The decision was hers; but my advice was to terminate the pregnancy-implicitly not only to lose the fetus but also the possibility of any future pregnancy. She decided to go ahead with the abortion, which she would not have done without my advice -indeed, my advocacy. My advice had begun from the relevant empirical data, but then became a moral judgement. Clinical judgements cannot be purified of moral and hence contestable elements under the British 1967 Abortion Act. ${ }^{22}$ Death of the mother was not inevitable and possible improvements in medical care may have made it less likely than the published data. If I had taken the most conservative Roman Catholic position that a fetus is a person from conception, I would have had to accept the position that killing the fetus was morally worse than risking the mother's life by continuing the pregnancy. The premeditated termination of one person's life would not be permissible to save another life. Instead, by basing my moral reasoning on the overall Christian belief in the sanctity of human life, I believed that wasting human life in that abortion was justified by the minimisation of the overall frustration of human life that the pregnancy's continuation might have entailed.

But if religious conviction had led me to the conservative position, my religious objection would have had no bearing on my duty to inform the patient of the facts and, among those facts, the facts of her legal entitlements. Tolerance means respecting her conscientious choice, not frustrating it by withholding information. Against this, my integrity-the call of conscience based upon my religious values-would involve my saying, 'not through me'. Tolerance is meaningless unless it respects views that may alter practice. The doctor has a duty to inform the patient (unless legally forbidden from doing so) of any healthcare choice within the boundaries set by the law, together with an obligation to make that choice possible. In this scenario, that would mean referring to another doctor with a less conservative viewpoint. But if I took a still more conservative stance, I might argue that referring to another doctor is colluding in killing an innocent person-that is, murder. I do not believe this view is held by any major Christian organisation and is outside the consensus view in society at large.

Christians understand that humanity is related to God. In the creation myths, God 'created man in his own image; in the image of God he created him; male and female he created them, ${ }^{23}$ How this image is construed is debated (rationality, creativity, love, and so on), as is the way that it might be interpreted in the person of Jesus Christ. ${ }^{24}$ But its consequence in good medical ethics lies in applying the wisdom of the long traditions of Christian writing, thinking, worship and practice. Christians have not been alone in their assertion of the intrinsic, as opposed to the instrumental, value of human life. All are one and all shall count as one. Many others would hold a similar belief, ${ }^{25}$ as Dworkin argues. However, Christians have been the most consistent advocates of this viewpoint, defenders of the vulnerable, and good medical ethics continues to benefit from that voice. Nobody would dispute that there has been much bad Christian religion, many bad Christians and many bad Christian institutions. Against that, the continuing Christian assertion of human value and loving my neighbour remains central to its ethics and its eschatology. It is an example of a perspective that benefits 'good medical ethics'.

\section{Competing interests None.}

Provenance and peer review Commissioned; internally peer reviewed.

\section{REFERENCES}

1 Davidson I. Theology's business. Inaugural Lecture, University of Otago, 2007.

2 Williams R. On Christian theology. Oxford: Blackwell, 2000:131 (Williams is speaking particularly of Christian discourse)

3 Obituary: Isaac Bashevis Singer. The Guardian, 26 Jul 1991.

4 Crenshaw JL. Old Testament wisdom: an introduction. London: SCM Press, 1981.

5 Scruton R. The return of religion. In: Scruton R. The Roger Scruton Reader. London: Continuum, 2009:128.

6 Holy Bible. Job 42:1.

7 Ward K. God. A guide for the perplexed. Oxford: One World, 2002:103.

8 MacGregor G. Introduction to religious philosophy. London: Macmillan, 1964:1.

9 Ward JN. The following plough. London: Epworth Press, 1978:13.

10 Cupitt D. God and the cosmos. The Listener, 1981:21.

11 Küng H. Does God exist? London: Collins, 1980.

12 Russell B. Religion and science. Oxford: OUP, 1935:8.

13 McPherson T. Philosophy and religious belief. London: Hutchinson, 1974:2.

14 Ward K. God, chance and necessity. Oxford: Oneworld, 1996:97.

15 Vidler AR. Quoted in: Soundings: essays concerning Christian understanding. Cambridge: CUP, 1962.

16 Fraser A. Cromwell. Our chief of men. London: Weidenfeld \& Nicolson, 1973:568.

17 Locke J. An essay concerning human understanding (5th edition 1706). London: Penguin Books, 1997:IV,XX,4.

18 See, for example, the moving piece by the Bishop of Worcester, $A$ precious end to life, in which he states, "I am opposed to this (assisted dying) bill not on religious grounds, but out of concern for the weakest and most vulnerable in our society". The Guardian, 18 July 2014:32.

19 Robinson JAT. Christian morals today. London: SCM Press, 1964:12.

20 Williams R. Secularism, faith and freedom. In: Faith in the public square. London: Bloomsbury, 2012:35.

21 Dworkin R. Life's dominion. An argument about abortion and euthanasia. London: HarperCollins, 1993:68. See also pp 35 et seq where he argues that the Roman Catholic church has changed the grounds for its objection to abortion.

22 Boyd K, Callaghan SJ, Shotter E. Life before birth: consensus in medical ethics. London: SPCK, 1986:53.

23 Holy Bible. Genesis 1, 27

24 Ford DFF. Theology. A very short introduction. Oxford: OUP, 1999:66.

25 Roy Hattersley, former deputy leader of the UK's Labour party, writing in the Guardian in 1987, for example, "God does not exist... all I have to believe in is the absolute sanctity of life. My opposition to capital punishment and abortion are all of a piece. I am opposed to killing people ... The decision about miserable life or merciful death is not one which we are entitled to take for others. And the others must include unborn babies." ("In praise of life-and young Mr Lawson"). 